\title{
Wanita Karir Dan Problem Pendidikan Anak
}

\author{
A. Fatah Yasin \\ Penulis adaiah Dosen Fak. Tartiyah UIIS Malang, kinisedang mengikuti \\ Program S-3 di IAIN Sunan Ampel Surabaya
}

\begin{abstract}
Interaction is perceived as an important need to create a harmonious family. Every person is equipped with the capability to interact with other but not many persons are able to have good interactions with others. People commonly think that a family with a "career woman" mother does not have sufficient good interactions. This paper shows, however, that a career women family can have more conducive environment to obtain a good interaction. It can be shown that the "career woman" mother is able to create intensive qualified interactions among the family members.
\end{abstract}

\section{A. Latar Belakang Masalah}

Pesatnya kamajuan dunia global terutama dalam bidang IPTEK, dan sekaligus bergulimya era reformasi di Indonesia, menuntut adanya keterbukaan, kebebasan berpendapat, berprilaku, dan kebebasan menuntut hak, yang seolah-olah masyarakat tidak mengenal lagi paksaan untuk mengikuti aturan dan kebijakan yang selama ini telah dibuat oleh pemerintah maupun yang dibentuk oleh tradisi budaya. Munculnya kebebasan pers dan bebasnya tayangan televisi swasta di Indonesia akhir-akhir Ulul Albab, Vol. 3 No. 2, 2001 


\section{6

ini, dianggap sebagai penyebar radiasi limbah budaya, penyebar liberalisme, pensosialisasi tata nilai Barat yang bertentangan dengan nilai-nilai budaya ketimuran. Hal inilah kemudian sangat cepat mempengaruhi pola prilaku dalam masyarakat.

Pola perilaku Individu dalam masyarakat dewasa ini, sangat terkesan sibuk dengan urusannya masing-nasing kanpa adanya kompromi secara terbuka, bahkan lupa taiggung, jwab dalam sebuah kelwarga yang sesuai dengan peranny wasingmasing. Pola hitup manusia seba diukur dengan ekonomi (aconomic orentel), sebagaimana yang dingkapkan cleh Becker dalam analisis "inter generation transfer", yasgmenussatkan pethatian: "bagaimana keluarga melakukan "invesiasi' (perhtungan untung rugi ) pada anak anak mereka, berapa banyak waktu yang sedia "dikorbankan" oleh orang tua untuk kepentingan anak-anak mereka, orang tua sibuk mencan tanbahan ekonomi sekaligus ingin mempertahankan status sosilnya agar lebih establis. ${ }^{1}$ Padakal Keluarga merupakan institusi penting dalam memberikan perar bagi perkembangan anak, sebagaimana yang dikatakan oleh Soerjono Soekano, ${ }^{2}$ baliwa keluarga batih (inti) itu seharusnya berperan sebagai : "Pelinâung" bagi pribedinpribadi yang menjadi anggota, dimana ketentraman dan keteribar diperoleh dalan wadah tersebut. Rahkan menurut J.R. Eshemen, ${ }^{3}$ keluarga memptinya fmusi utama adalak proses sosialisasi, terutama pada anak. anak.

Secara general anak dapat ditafsirkan sebagai generasi penerus bagi orang tua, agama, masyarakat dan bangsanya. Semua orang tua berharap kepada anaknya agar kelak menjadi manusia berkuwalitas, yaitu beriman dan bertaqwa terhadap Tuhan Yang Maha Esa, berbudi pekerti luhur, berkepribadian, mandiri, maju, tangguh, cerdas, kreatif, terampil, berdisiplin, beretos kerja, profesional, betanggung jawab, produktif, dan sehat jasmani - rohani. ${ }^{4}$ Oleh karenanya, pembinaan pendidikan anak melalui pola interaktifkeseharian, menjadi tanggung jawab bersama, terlebihlebih peran keluarga, dalam hal ini peran orang tua (Ibu) sangat dominan. Secara fisik figur orang tha bagi anak adalah seorang manusia tangguh yang dianggap mampu melindungi, mampu membantu semua ketidak mampuan anak, tempat curahan hati, dain bekkan dianggap sebagai tempat konsultasi semua kegiatan anakanaknya. Jika anak intensitas bertemunya dengan orang tua kurang, bisa saja anal kemungkinan mengalami kekecewaan, minder dan lain sebagainya karena pada saat ia menyebut orang-tuanya, la tidak ada di rumah. Untuk itu upaya menghasilkan kualitas anak yang ideal sudah barang tentu akan terpulang pada peran orang tua 
terhadap anaknya, terutama Ibu yang dalam kehidupan keluarga memegang peranan penting sebagai pengasuh anak-anaknya. Artinya, seberapa besar orang tua (Ibu) memberikan perhatian melalui interaksi dan komunikasi secara baik dan berkualitas terhadap anaknya?. Persoalan ini seringkali menjadi pertanyaan yang tidak pernah kunjung berakhir.

Pemikiran di atas, menunjukkan bahwa interaksi merupakan kebutuhan yang mutlak bagi setiap manusia dalam kehidupan sosialnya, terlebih-lebih dalam kehidupan keluarga. Kendatipun setiap individu memiliki kemampuan untuk berinteraksi, namun teryata mengapa berinteraksi dengan baik dan benar sangat sulit untuk diterapkan, terutama pada keluarga yang wanita (Ibu)-nya karier. Banyak interaksi terjadi dan berlangsung dalam kehidupan keluarga khususnya keluarga tak berkarier tetapi kadang-kadang tidak bermakna bagi anggota keluarga (anak) atau tidak mengena pada sasaran, tentang apa yang dimaksudnya, bahkan kadangkala justru menjadi bumerang bagi anak, namun sebaliknya ada juga keluarga (Ibu) berkarir tapi justru peranan dalam pembinaan anaknya lebih bagus. Hal ini sebagaimana dikatakan oleh Louis W.H, ${ }^{5}$ bahwa thu yang tidak bekerja peluang ketemu anak lebih besar namun interaksinya yang positif lebih sedikit, sementara Ibu yang bekerja intensitas bertemu anak sedikit tapi kualitas interaksinya besar, karena Ibu yang bekerja lebih memahami hakekat interaksi dari pada Ibu yang tidak bekerja. Ibu (bekerja/karir) yang memahami hakekat interaksi seperti tersebut, adalah Ibu yang mengenyam pendidikan tinggi. Lalu yang menjadi persoalan sekarang adalah kapan dan bagaimana cara atau peran yang dilakukan oleh Ibu yang bekerja (karir) dalam melakukan interaksi dengan anak sehingga disebut kualitasnya baik, padahal jarang ketemu denganya (anak-anaknya)?.

Berpijak dari latar belakang uraian persoalan di atas, tampaknya menarik untuk diteliti mengenai bagaimana pola interaksi yang dilakukan oleh wanita (lbu) karir terhadap pendidikan anak? dan hal-hal apakah yang menjadi problem wanita (lou) karir dalam proses pendidikan anak ?. Oleh karena itu dalam penelitian ini pada dasamya adalah bertujuan untuk menjawab kedua pertanyaan tersebut dengan cara mendeskripsikan secara kualitatif. 


\section{B. Perspektif Teori dan Kajian Terdahulu.}

Dalam perspektif sosiologis, anak sebagai individu selalu merespon situasi yang dihnadapi melalui proses imitasi (peniruan). Apabila situasi yang direspon salah, anak akan berkembang atau berubah menjadi salah dalam berprilaku. Teori model pertukaran sosial misalnya, memandang bahwa hubungan interpersonal adalah suatu transaksi dagang. Asumsi yang mendasari analisis ini menganggap bahwa setiap individu secara sukarela memasuki dan tinggal dalam hubungan sosial hanya selama hubungan tersebut cukup memuaskan ditinjau dari segi ganjaran dan biaya. ${ }^{6}$ Teori atribusi yang oleh Heider dikatakan bahwa, jika kita melihat prilaku orang lain, maka kita juga harus melihat apa sebenamya yang menyebabkan seseorang berprilaku seperti itu. ${ }^{7}$ Untuk itu seseorang harus mempunyai daya prediksi terhadap perilaku orang lain, mengapa ia bertindak, siapa yang mempengaruhi dan bagaimana tindakan selanjutnya dst. Dalam teori penetrasi sosial Altmen dan Taylor, mengatakan bahwa hubungan antar pribadi (interpersonal) melewati suatu proses kontinyu, berubah dalam pelbagai fenomena perilaku yang ditunjukkannya. ${ }^{8}$ Teori Sosiologi dengan paradigma definisi sosial yang dilontarkan oleh Ritzer $^{9}$ mengatakan bahwa, perilaku manusia merupakan hasil interaksi antara faktor-faktor bawaan dengan lingkungan. Lingkungan merupakan aspek terpenting dalam pembentukan perilaku (kepribadian) anak manusia, karena di dalamnya terjadi proses sosialisasi. Oleh karena itu lanjut Ritzer, kehidupan bermasyarakat terbentuk melalui proses interaksi dan komunikasi antar individu dengan individu, antar kelompok, dan dengan mengunakan simbol-simbol yang dipahami maknanya melalui proses belajar.

Teori pembentukan sikap dalam pandangan behavioristik, menganggap bahwa, tingkah laku itu merupakan hasil belajar dari lingkungan. Karenanya pembentukan kepribadian (perilaku) merupakan hasil responsi terhadap lingkungan, termasuk yang sangat menentukan adalah lingkungan keluarga. ${ }^{10} \mathrm{John}$ Locke dengan teori tabuia rasa -nya juga mengatakan bahwa jiwa manusia itu ibarat kertas kosong tak berisi, akan menjadi terisi jiwa manusia itu tergantung dari bentukan pengalaman lingkungan. ${ }^{11}$

Berdasarkan beberapa kajian teori di atas, ada beberapa hasil penelitian terdahulu yang membicarakan tentang perilaku orang (lbu) atau anak dalam suatu interaksi. Milton Chen, ${ }^{12}$ dalam penelitiannya tentang Anak-anak dan televisi pada 
bagian tertentu menyimpulkan bahwa jika orang tua (Ibu) menginginkan anaknya berprestasi maka anak seyogyanya mendapat dorongan, perhatian, tanggapan secara serius dari orang tua dan meluangkan waktu cukup lama untuk kegiatankegiatan pengembangan bakat si anak. Hasil penelitian Charles Schaefer ${ }^{13}$ tentang Bagaimana Mempengaruhi Anak, memberi kesimpulan bahwa, cara untuk mempenganuhi ano: agar bertingkah laku positifadalah menjalin hubungan interaktif - harmonis dalam keluarga.

Akan tetapi dari hasil penelitian di atas, penulis berkecenderungan untuk menambah atau memperluas atau bahkan ingin mempertegas pada kasus wanita karir lainnya seperti dalam penelitian yang telah penulis lakukan ini mengenai "Wanita Karir dan Pendidikan Anak" sehingga khazanah keilmuan di bidang pendidikan anak dan wanita semakin banyak. "Wanita Karir adalah seorang wanita (ibu) yang berstatus karir atau bekerja di luar kehidupan institusi keluarga untuk mencari nafkah (penghasilan ekonomi), namun demikian bekerja karir bukanlah bekerja biasa, tetapi karir lebih merupakan ketertarikan pada suatu pekerjaan yang dilaksanakan dalam waktu lama untuk mencapai kenaikan prestasi lebib tinggi. ${ }^{14}$

\section{Metodologi Penelitian.}

Penulis dalam penelitian ini menggunakan pendekatan kasus, yaitu suatu pendekatan yang bertujuan untuk mempertahankan keutuhan dan kedalaman dari obyek yang diteliti. Penelitian kasus ini dilakukan terhadap kesatuan sosial khusus yang dipillih, sebagai bahan kajian untuk memahami agregat sosial atau kesatuan sosial yang lebih luas. Yang dimaksud kesatuan sosial yang lebih luas adalah interaksi kehidupan keluarga pada umumnya. Sedangkan unit sosial (kesatuan sosial khusus) yang dijadikan obyek penelitian dalam tulisan ini adalah interaksi kehidupan keluarga yang bersangkutan (yang diteliti). Penelitian ini tidak dapat digeneralisasikan di luar komunitas yang diteliti, namun bisa dijadikan sebagai alat analisis untuk membaca fenomena aktifitas kehidupan lembaga sosial (keluarga) pada komunitas lain, yang kebetulan memiliki watak dan karakteristik yang hampir bersamaan.

Adapun obyek yang dijadikan kasus dalam penelitian ini adalah Keluarga Ibu Inul (nama samaran), dengan alasan bahwa Ibu Inul adalah seorang Ibu numah tangga yang dalam kesehariannya bekerja sebagai seorang dosen di perguruan 
tinggi cukup ternama di kota Malang, dan Ia memiliki anak yang masih berusia antara 7 sampai 15 tahun dan sedang duduk di bangku SD - SLTP. Menurut hemat peneliti usia anak yang tersebut di atas, merupakan usia yang masih relatif banyak membutuhkan "keberadaan" orang tua dalam mendampingi kehidupannya atau dengan kata lain anak dalam usia ini tingkat "ketergantungannya" kepada orang tua masih relatif tinggi.

Pengumpulan data dalam penelitian ini dilakukan melalui observasi, wawancara dan dokumenter. Adapun yang dijadikan responden/Informan dalam penelitian ini adalah keluarga Ibu Inul (Bapak, lbu, anak, dan semua orang yang tinggal bersamanya dalam institusi keluarga tersebut), dan atau tetangga dekat yang dianggap perlu. Sedangkan analisis datanya menggunakan analisis kualitatif, yang biasa digunakan dalam penelitian eksploratif, yaitu analisis deskriptif (dengan beberapa tahapan, yakni mencermati pola tindakan individu yang dianggap penting sehingga menghasilkan deskripsi, mengidentifikasi ciri-ciri fenomena intraksional tertentu, identifikasi-klarifikasi dan kategorisasi, kemudian akan ditemukan hipotesis-hipotesis sebagai hasil penelitian, dan selanjutnya akan diinterpretasikan melalui penjelasan-penjelasan deskriptif.

\section{Rangkuman Hasil Penelitian}

Rangkuman dari hasil penelitian dalam tulisan ini dapat kami laporkan bahwa, Ibu Inul (nama samaran) adalah warga negara Indonesia asli keturunan Jawa, berkelakuan baik dan taat menjalankan ajaran agama Islam yang dianutnya. Ia adalah anak terakhir (kelima) dari lima bersaudara, dan lahir 37 tahun yang lalu di suatu desa kecil bagian utara wilayah Jawa Timur.

Latar pendidikan Ibu Inul adalah menamatkan jenjang pendidikan MI, MTs, MA, PTAIN dan sampai pada jenjang Magister (S-2). Ibu Inul memulai hidup berumah tangga pada tahun 1986 (umur 19 th.) dengan suami yang bernama Anang (nama samaran 25 tahun) PNS, sekarang Ia dikaruniahi 2 (dua) orang anak (laki-laki dan perempuan). Anak pertama bernama Aji (nama samaran umur 15 tahun) sekarang duduk di bangku sekolah kelas 1 SLTA dan anak kedua bernama Pangestu (nama samaran umur 8 tahun) sekarang duduk di bangku pendidikan dasar kelas 3. 
Ton twul sekarang ini bekerja (berkarir) sebagai seorang dosen (PNS) dan sekaligus sebagai pejabat struktural tingkat fakultas di salah satu perguruan tinggi negeri di kota Malang. Ia sering kerja lembur, berangkat pagi pulang malam. Sering pula Ia menghadiri kegiatan-kegiatan (dinas) di luar kota, sehingga harus berharihati thak pulang. Dikhat dar staus sosialnya Ibu Inul adaleh tergolong orarg

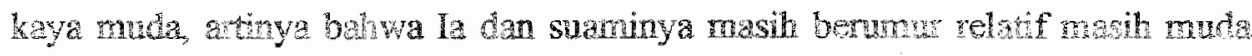
tetapi sudah memik penghasilan dan kokayan yang cukw. Ia manilik dua rumak, sebidang tanah (kavling) Jan sebidang sawah (warisan crang twa), serta penghesilar. keluarga rata-rata setiap bulanya mencapai 3.500 .000 (tiga juta lima ratus riby rupiah). Penghasilan tersebut diperoleh dari hasil kerja suami-lstri dan peng"asilan dari hasil sewaan rumah dan panen sawah.

Perjalanan pendidikan kedua analk Ibu Inul (Aji dan Pangestu) adalah cuhap menyenangkan bagi kedua orang tua. Aji sejak lulus dari TK (umur 6 tahw) selak diterima masuk sekolaki negeri yang cukup favorid di kota Malang, yain MN Malang I, (lulus 1999) kernudian masuk SMP Negeri I (ulus 2002) kini ia masul di SMU Negeri I Malang. Selama menempuh pendidkan di MN Malang I wrsebut, Aji telah memperoleh prestasi yang memuaskan, yaitu selalu memperoleh ronghing satu atau dua di kelasnya, dan pada tahun terakhir belajar di MNN tersebut, Ia memperoleh penghargaan berupa tropi dari kepala madrasah atas prestasinya memperoleh nilai 10 mata pelajaran matematika dari hasil ujian ebtanas, dan juga termasuk sepuluh besar lulusan terbaik dari almamaternya. Begitu juga kaktu di SLTP tidak begitu kalah dengan teman-temannya, sampai pada akhimya lulus dan bisa masuk ke SMUN I Malang tersebut.

Sedangkan anak kedua Ibu Inul Pangesta adalak anak yang cukwp rethe, jujur, lincah dan berkelakuar baik, taat sama kedua orang tua, selalu num dih rön menjalankan ibadah sholat, hampir sama dengan kakaknya (Aji). Sejak lulus dari TK (umur 6 tahun) Ia diterima masuk MIN Malang I mengikut jejak kakakaya. Pada tahur pelajaran 2002-2003 sekarang ini, Pangestu sudah memasuki kelas tiga $\mathrm{A}$, dan hampir sama dengan perjalanan kakaknya, pada tiap kenaikan kelas nilai rapornya memperoleh prestasi yang cukup menggembirakan, yaitu peda kelas satu dan dua selalu memperoleh rangking sepuluh besar di kelasnya. Dari penampilan sementara la memang anak yang memiliki bakat mandiri dan mudah berkreasi sendiri. Dengan kesibukan kedua orang tuanya la sering belajar sendiri tanpa dibarengi orang lain atau kedua orang tuanya. Dari aspek prilaku, sikap, cara bergaul 


\section{A. Fatah Yasin}

dan moralnya, kedua anak lbu Inul sangat baik, tidak seperti yang di duga banyak orang bahwa, anak yang sering ditinggal kerja oleh kedua orang tua biasanya tidak begitu terurusi (terabaikan) sehingga cara berpakaian, kebersihan, kedisiplinan, bahkan cara bergaul sangat kelihatan dari anak tersebut setiap harinya.

Dari deskripsi latar kehidupan keluarga Ibu Inul tersebut di atas, dapat diambil simpulan semestara bahwa kondisi kehidupan rumah tangga Ibu Inul sampai sekarang cukup harmonis, dalam artian tidak ada tanda-tanda perpecahan, percekcokan dan atau tidak ada tanda-tanda mengalami penyusutan dalam hidup, dan bahkan semakin nampak ada kecenderungan ke arah "establisment of life". Disamping itu perkembangan pendidikan kedua anaknya dapat dibilang cukup membanggakan, kendati Ibu Inul adalah sebagai seorang wanita (Ibu) karir. Pertanyaan yang muncul sekaligus sebagai fokus penelitian yang perlu dijawab dalam penelitian ini adalah bagaimana pola interaksi yang dilakukan oleh Ibu Inul terhadap dan atau dalam pendidikan anaknya, dan apa kesulitan yang di hadapi ketika melakukan interaksi dengan anaknya tersebut?.

Perlu diketahui bahwa esensi dari konsep pola interaksi adalah suatu bentuk interaksi interpersonal yang berlangsung tiap hari dalam kehidupan. Membicarakan tentang pola interaksi dalam keluarga termasuk yang dilakukan oleh Ibu Inul dengan anaknya, penulis (peneliti) dapat mengkategorikan menjadi dua, yakni (1) Intensitas - kualitas interaksi, yaitu seberapa besar sering-tidaknya bertemu dan melakukan interkasi serta bagaimana kualitas interaksinya dengan anak dalam kehidupan keluarga. (2) Pola interaksi terbuka - tertutup. Dikatakan interaksi terbuka apabila interaksi yang yang dilakukan (Ibu \& anak) bersifat langsung, spesifik, sebangun dan dapat mendorong pertumbuhan serta adanya aturan-aturan terbuka, baru, dan saling pengertian dan kepercayaan diantara lbu dengan anak atau sesama anggota keluarga. Sedangkan pola interaksi tertutup adalah ditandai dengan interaksi bersifat tidak langsung, tidak jelas, tidak spesifik dan tidak sebangun serta tertutup dan usang, bahkan bersifat feodal dan tidak adanya saling pengertian dan kepercayaan antara Ibu dengan anak atau antar individu (anggota) dalam kehidupan keluarga.

Dalam kehidupan sehari-hari selama ini, keluarga Ibu Inul sengaja tidak mengambil pembantu rumah tangga dan sepertinya sudah ada kesepakatan dengan suami mengenai proses merawat dan atau mengurusi kehidupan anak secara langsung, yakni suami lebih berperan banyak dalam urusan rumah tangga, mulai dari membangunkan tidur, memandikan, mengantar-menjemput sekolah, sampai

Ulul Albab, Vol. 3 No. 2, 2001 
pada mendampinggi belajar anak-anaknya, semuanya hampir dilakukan oleh suaminya. Bahkan dalam hal memasak, belanja ke pasar, mencuci, dan urusan kerumahtanggaan lain, porsi mengurusnya lebih dominan suami dari pada istri (Tbu Inul), bahkan kadang-kadang perkerjaan dinas Ibu Inulpun banyak dibantu suaminya.

Meskipun dirinya (Ibu Inul) sering meninggalkan anaknya di rumah, namun proses interaksi dalam keluarga dilakukan dengan penuh keterbukaan, baik secara langsung atau tidak langsung. Interaksi Langsung maksudnya apabila Ibu Inul sedang liburan di rumah Ia secara fisik bertemu dengan anaknya dan memanfatkan semaksimal mungkin pertemuan itu, yakni selalu mengecek seberapa besar hasil belajar atau perubahan tingkah laku keseharian, dan Ia selalu aktif mendekati dan bersahabat dengan anaknya, serta menanamkan rasa saling pengertian dan kepercayaan diantara anggota keluarga. Proses ini tampak pada cara menegur, memberi nasehat dan cara melarang anak yang berprilaku atau melakukan sesuatu yang tidak sesuai dengan kehendak orang tua. Penulis dalam penelitian ini sepakat bahwa orang tua mengendalikan, membatasi, dan melarang tingkah laku tertentu bagi anaknya adalah benar asal dilakukan dengan beberapa cara yang "cerdik" sehingga anak melihatnya bukan sebagai suatu yang menolak dirinya, melainkan tingkah lakunya. Itulah sebabnya orang tua dituntut untuk dapat ber-empati kepada anaknya, sehingga anak mau menjadikan dirinya sebagai "Frame of reference dan field of experience". Supaya anak tidak terlalu sering dituturi atau didekte dengan kata-kata karena Ibu jarang di rumah, maka untuk melatih kemandirian berbicara dan daya rekam ingatan, anak harus diberi kebebasan untuk berbicara dan bercerita tentang suatu pengalamannya dari lingkungan sekolah ataupun lingkungan bermainnya, Ibu Inul mendengarkan secara aktif untuk dapat mengerti dan memahami pembicaraan dan cerita anaknya. Dalam kondisi demikian akhirnya terjadi apa yang disebut "Homophilius", derajat kesamaan antara kedua belah pihak. Selain derajat kesamaan, masih ada faktor-faktor lain yang dapat menentukan efektif tidaknya interaksi dalam keluarganya. Sebagaimana yang dikatakan oleh Churden dan Shermen ;' "bahwa jika menghendaki interaksi efektif, seorang interaktor harus : memeperhatikan umpan balik (feed back) dan mau mendengarkan komunikannya, memiliki kejujuran dalam menyampikan pesan, mengetahui kebutuhan manusia, mampu memilih yang tepat, mampu memilih dan memafaatkan saluran dan media yang tepat". 


\section{A. Fatah Yasin}

Sedangkan interaksi tidak langsung maksudnya, dalam kehidupan keseharian intensitas bertemu secara fisik antara lbu Inul dengan anak-anak secara kuantitas tergolong kurang dibanding dengan suaminya. Namun demikian Ibu Inul meskipun secara kuantitas jarang atau kurang dalam melakukan interaksi dengan anak-anaknya, tetapi Ia memiliki pola tersendiri antara lain yaitu ; (1) berpesan kepada anaknya sebelum Ia meninggalkan rumah, (2) berpesan kepada anggota keluarga terutama suami dan yang tinggal bersamanya agar selalu mendampinggi anaknya dalam hal apapun kegiatannya, (3) selalu memantau dari jauh atau selalu memantau dari luar rumah dengan cara menelpun langsung anaknya (4) titip pesan sama teman dan tetangga dekat mengenai anak-anaknya. (5) memfasilitasi atau menyediakan sarana belajar dan peralatan bermain sendiri di rumah seperti nenyediakan permainan game, play station di komputer, dan TV lengkap dengan perangkatnya di rumah, supaya mudah dikontrol waktu bermainnya.

Dari beberapa pola/cara yang dilakukan oleh Ibu Inul dalam melakukan interaksi dengan anaknya ternyata masuk kategori kuantitas rendah, tetapi berkualitas tinggi, karena anak masih selalu merasakan sentuhan pola interaksi setiap hari, bahkan setiap waktu walaupun tidak secara langsung bertemu fisik. Dan bahkan Ibu Inul punya kiat tersendiri untuk bisa membuat anaknya mentaati pesan yang disampaikan tersebut, yaitu selalu memberikan hadiah kepada anaknya sesuai dengan kesukaan atau kebutuhan dan keperluan duniannya anak.

Di samping itu, dari beberapa indikator sebagaimana tersebut di atas pula, interaksi yang dilakukan oleh lbu Inul sebagai wanita karier terhadap anaknya, dapat dikategorikan sebagai pola inieraksi terbuka bukan tertutup, karena adanya beberapa alasan sebagai berikut : (a) Proses penyampaian pesannya tidak bersifat "otoriter", tetapi bersifat "demokratis" bahkan lebih bersifat "permisif". Artinya, orang tua (Ibu Inul) tidak memaksakan kehendaknya kepada si anak, tetapi anak diarahkan dan diberi pengertian serta pemahaman atas sesuatu yang diperbuat, seperti ketika anak berbahasa yang kurang baik dan kurang sopan, ketika anak tidak mematuhi perintah orang tua dan atau kurang memperhatikan saran orang tua. (b) Isi pesannya lebih menekankan pada "persuasif" yang dapat membantu dan mendorong perkembangan keperibadian anak. Artinya, orang tua berupaya mengemas (mengkode) pesan sedemikian rupa, sehingga anak tidak merasa disalahkan begitu saja. (c) Intensitas berinteraksi dengan anaknya relatif cukup dan bermakna, meskipun tidak dilakukan secara langsung. 
Tou Inul meskipun telah menggunakan berbagai pola, cara, model dalam berinteraksi dengan anaknya sebagaimana tersebut di atas, nampaknya masih menemui beberapa problem dalam berinteraksi dengan anak, meskipun tidak begitu sulit memecahkannya. Perlu diakui bahwa, secara umum anak memerlukan perhatian, memerlukan kontak pribadi dengan orang tua, memerlukan interaksi yang bersifat fisik, dan umumnya pula anak akan melakukan proses simpati, sugesti, imitasi dan bahkan identifikasi beberapa karakter orang tuanya untuk ditransfer ke dalam diri anak tersebut. Karena itu kehadiran Ibu dalam rumah tangga merupakan kebutuhan psikis anak, terutama bagi anak yang belum terbentuk kemandiriannya. Sementara itu, dengan komitmen kerja seorang Ibu harus melaksanakan tugas kerjanya dan bahkan berusaha terus agar karir kerjanya dapat meningkat dengan tujuan mengabdi dan meningkatkan kesejahteraan keluarganya. Akan tetapi tuntutan akan perkembangan jiwa anak juga sangat penting, maka disinilah muncul beberapa persoalan yang dihadapi oleh Ibu yang bekerja di luar rumah atau wanita karir terhadap persoalan kehidupan keluarganya, terutama pada perkembangan kepribadian anak-anaknya.

Ibu Inul sebagai wanita karir, ternyata dalam kehidupan keluarganya juga sering mengalami problem kerumahtanggaan meskipun tidak begitu berat, hal tersebut sebagaimana dituturkan oleh anggota keluarganya (informan) bahwa, Ibu Inul sering mengerjakan pekerjaan yang setumpuk dan kadang sulit membagi waktu menyelesaikannya, sehingga suami sering ketiban printah, kemarahan dan omelan, pergaulan sosial di lingkungannya sering ditinggalkan, dan bahkan yang paling sering adalah melimpahkan pekerjaan kepada orang lain. Dan anehnya lbu Inul selama ini belum pernah mencari pembantu untuk mengurusi keluarganya, ini adalah sesuatu yang luar biasa, tidak seperti umumnya wanita karir.

Tentang problem yang dianggap sulit dan dialami oleh Ibu Inul dalam proses pendidikan anak dalam keluarga adalah dapat disebutkan sebagai berikut yaitu : (1) Kesulitan pengasuhan anak sejak usia dini, sehingga sering diserahkan pada anggota keluarganya, seperti diserahkan ke ibunya, suaminya, keponakannya, terlebih-lebih pada saat Ibu Inul masih menitih jenjang karir awal. (2) Kesulitan memberikan ASI pada anak bayinya diwaktu kecil, terutama pada anak kedua (Pangestu) yang pada waktu itu masih sangat membutuhkan sesuai dengan ajaran agama, sehingga hampir setiap hari bayinya dibantu dengan susu kaleng (dot). (3) Sering meninggalkan keluarga atau terbatasnya waktu di numah sehingga tidak 


\section{6}

cukup atau kurang dalam mendampinggi bermain anak secara penuh, terutama tatkala anak sedang asik-asiknya nonton TV dengan acara kesukaannya sehingga lupa belajar atau lupa akan pengaruh TV tersebut. (4) Ada sedikit kesulitan dalam mendisiplinkan anak, sehingga semuanya harus dikerjakan oleh ayahnya (suami Ibu Inul). (4) Kesulitan dalam hal transportasi apabila memenuhi ajakan anak ke luar rumah, karena memang Ibu Inul tidak bisa mengendarai sepeda motor atau mobil, sehingga harus minta antar orang lain atau naik angkutan umum.

Secara umum Ibu Inul menganggap bahwa hal-hal di atas, tidaklah menjadikan anaknya terlantar akan pendidikan (belajarnya) atau kegiatan berprilaku lainnya, karena Ibu Inul selalu mengharapkan partisipasi atau keterlibatan semua anggota keluarga yang tinggal serumah dalam membimbing, mengarahkan dan atau mendisiplinkan kegiatan anak. Sehingga anak-anaknya masih mentaati semua kebijakan yang dibuat oleh kehidupan keluarga. Namun demikian, Ibu Inul merasa ada kesulitan betul dalam proses pendidikan anaknya pada saat Ia dan suaminya sama-sama ada kegiatan yang membutuhkan waktu lama di luar rumah, sehingga kadang anak-anak tidak terpantau aktivitasnya dengan baik. Anang (suami Ibu Inul) ketika di tanya tentang kegiatan karir Istrinya tidak begitu mempersoalkan, bahkan mendukung sepenuhnya, dan Ia rela menerima tugas ngurusi keluarga. Yang terpenting bagi Anang adalah anak-anak harus diberi pengertian tatkala ia belum mengerti, dijelaskan ketika bertanya, dibantu ketika membutuhkan, didampinggi ketika butuh kasih-sayang, dan itu semua tidak harus ibunya kendati dalam sebuah teori menyebut seorang lbu memegang peranan dalam mengasuh kepribadian anak. Namun yang perlu diperhatikan jangan sampai anak terlantar karena Ibunya tidak ada di rumah, sebab Ibunya bekerja itu juga untuk anak, sehingga kalau anak terlantar berarti pekerjaan Ibunya itu tak bermakna apa-apa. Untuk itu Anang menjelaskan bahwa dalam kehidupan keluarga yang perlu ditradisikan adalah suasana interaksional yang terbuka baik langsung maupun tidak langsung, dengan menjelaskan hal-hal yang belum jelas atau yang menjadi problem dalam kehidupan keluarga, sehingga anak merasa terbentuk prilakunya, sikapnya dan terpenting adalah kecerdasannya dari situasi kehidupan keluarga sebagai sumber belajar yang pertama dan utama.

Dari beberapa paparan di atas, penulis dapat mengatakan, "bahwa interaksi adalah merupakan stimulus yang membawa respon perilaku atau opini yang bisa diamati dan selanjutkan akan ditunjukkan dengan sikap". Singkatnya, "tingkah laku 
seseorang (anak) itu merupakan hasil belajar dari lingkungannya (terutama bermula dari kehidupan keluarga)". Teori ini mengingatkan penulis pada satu sajak yang ditulis oleh Dorothy Law Nolty, yang berjudul "Children Learn What They Live" ${ }^{16}$ sebagai berikut :

Jika anak dibesarkan dengan celaan, Ia belajar memaki.

Jika anak dibesarkan dengan permusuhan, Ia belajar berkelahi.

Jika anak dibesarkan dengan cemoohan, Ia belajar rendah diri.

Jika anak dibesarkan dengan penghinaan, Ia belajar menyesali diri.

Jika anak dibesarkan dengan toleransi, Ia belajar menahan diri.

Jika anak dibesarkan dengan dorongan, Ia belajar percaya diri.

Jika anak dibesarkan dengan pujian, Ia belajar menghargai.

Jika anak dibesarkan dengan sebaik-baiknya perlakuan, Ia belajar keadilan. Jika anak dibesarkan dengan rasa aman, Ia belajar menaruh kepercayaan. Jika anak dibesarkan dengan dukungan, Ia belajar menyenangi diri.

Jika anak dibesarkan dengan kasih sayang dan persahabatan, Ia belajar menemukan cinta dalam kehidupan.

Rangkuman hasil penelitian dan sajak di atas, merupakan satu pengetahuan tentang betapa dominannya pola interaksi keluarga dalam proses pendidikan anak. Perlu juga dipahami bahwa, perkembangan manusia itu merupakan hasil interaksi antara faktor-faktor bawaan (dasar) dan faktor lingkungan (ajar), sehingga meskipun wanita karir itu dianggap kurang intensif dalam melakukan interaksi secara kuantitatif, tetapi sebenamya yang terpenting adalah seberapa besar kualitas interaksi itu berlangsung, walaupun Ibu tidak ada di rumah, tetapi upaya mendesains suasana belajar tetap bisa diciptakan dengan baik dan anak tetap dalam kondisi selalu belajar-dan belajar, seperti sebagaimana yang dilakukan oleh Ibu Inul di atas. Semoga bermanfaat !!! 


\section{A. Fatah Yasin}

\section{Endnotes}

Aris Ananta, 1994. Kebijakan Mengenai Keluarga. Prisma, No. 7.

2 Soerjono Soekanto, 1990. Sosiologi Keluarga:Tentang Ikhwal Keluarga, Remaja, dan Anak, Jakarta : Reneka Cipta, hal. 23.

3 J.R. Eshlemen, 1978. The Family : An Intruduction. Boston: Allyn and Bacon Inc, hal. 86.

4 Hadi Subeno, TV, Pendidikan dan Kepribadian Anak. Surya : 28 Nopember 1994.

\$ Louis W.H, 1975. Effect on Child. Dalam Working Mothers. London : Jossy Bass Publisher, hal. 143-145.

6 Jalaluddin Rahmat, 1988. Psikologi Komunikasi. Bandung : Remaja Rosydakarya, hal. 137.

7 David Sears dkk., 1992. Psikologi Sosial. Alih Bahasa Micail Adryanto. Jakarta : Erlangga, hal. 92.

8 Alo Liliweri, 1991. Komunikasi Antar Pribadi. Bandung : PT. Citra Aditya Bakti, hal. 5455 .

- George Rirtzer, 1992. Sosiologi Ilmu Pengetahuan Berparadigma Ganda. Penyunting Alimandan. Jakarta : Rajawali Press, hal. 69

10 Dedy Djamaluddin Malik, dkk., 1993. Komunikasi Internasional. Bandu8ng PT. Remaja Rosydakarya, hal. 92.

1 E. Koeswara, 1991. Teori-teori Kepribadian:Psikoanalisis, Behaviorisme Humanistik. Bandung :Eresco, hal. 23.

12 Milthon Chen, 1996. Anak-anak dan Televisi. Jakarta : Gramedia, hal. 10.

13 Charles Schaefer, 1994. Bagaimana Mempengaruhi Anak. Semarang : Dahara Prize, hal. 40 .

14 Kathlen Gerson, 1985. Hard Choices How Women Deside About Work Carier and Motherhood. University of California, hal. 126

15 Lihat, Masmuh, 1997. Komunikasi Keluarga. Malang : UMM, hal 89.

16 Lihat Jalaluddin Rahmat, 1991. Islam Aktual. Bandung : Mizan, hal 187. 


\section{Bibliography}

Alo Liliweri, 1991. Komunikasi Antar Peribadi. Bandung : PT. Citra Aditya Bakti.

Aris Ananta, 1994. Kebijakan Mengenai Keluarga: Suatu Kebijakan mengenai Perekonomian. Prisma, No.7.

Barbara Gutek, Larwood, 1986. "Introduction Women's Careers are Important and Defferent' dalam Barbara Gutek dan Larwood eds. Women's Career Development. New Bury Park : Sage Publication.

Charles Schaefer, 1994. Bagaimana Mempengaruhi Anak. Semarang : Dahara Prize.

David Sears, dkk., 1992. Psikologi Sosial. Alih Bahasa Michail Adryanto. Jakarta : Erlangga.

Dedy Djamaluddin Malik, dkk. (Ed.) Kamunikasi Internasional. Bandung PT. Remaja Rosydakarya.

E. Koeswara, 1991. Teori-teori Kepribadian : Psikoanalisis, Behaviorisme, Humanistik. Bandung : Eresco.

George Rirtzer, 1992. Sosiologi Ilmu Pengetahuan Berparadigma Ganda. Penyadur Alimandan. Jakarta : Rajawali Press.

Hadi Subeno, 1994. TV, Pendidikan dan Kepribadian Anak. Surya : 28 November.

J. R. Eshleman, 1978. The Family : An Intruduction. Boston : Allyn and Bacon Inc.

Jalaluddin Rahmat, 1988. Psikologi Komunikasi : Edisi Revisi. Bandung : Remaja Rosyda Karya.

Jalaluddin Rahmat, 1991. Islam Aktual. Bandung : Mizan.

Kathlen Gerson, 1985. Hard Choices How Women Deside about Work Carier and Motherhood. University of California.

Louis W.H., 1975. Effect on Child. Dalam Working Mothers. London : Jossy bass Publishers.

Masmuh, 1997. Komunikasi Keluarga . Tesis : Malang UMM.

Milthon Chen, 1996. Anak-anak dan Televisi. Jakarta : Gramedia. 


\section{A. Fatah Yasin}

Soerjono Soekanto, 1990. Sosiologi Keluarga : Tentang Ikhwal Keluarga, Remaja dan Anak. Jakarta : Reneka Cipta.

Rahmat, Jalaludin. Islam Aktual. Bandung : Mizan, hal 187. 